\title{
CAMEROON FIGHTING BOKO HARAM
}

\author{
Jean Cottin Gelin KOUMA \\ Peoples' Friendship University of Russia (RUDN University), Moscow, Russia
}

\begin{abstract}
This study proposes to retrace Boko Haram atrocities in Cameroon as well as the history of international cooperation against the Islamist sect since the declaration of the war against it in 2014. The principal internal counter-terrorist efforts are shown, including establishement of "Operational Command" missions, partial reorganization of the territorial map of the army's command, the expansion of defense policy at the subregional level and the gradual redefinition of military, the allocation of resources and tools adapted to these new missions.

Cameroon engages in a process of multilateralization of the challenges of counter-terrorism cooperation, which gives a new dimension to the action of the defense and security forces as well as the multilateralization of the stakes of cooperation. The role of major powers and the countries of the subregion as well as the African Union and the United Nations is revealed. Cameroon is a traditional beneficiary of French military assistance. Counter-terrorist assistance also came from Russia, US, UK and Germany. The role of the Multinational Joint Task Force of Commission of the Lake Chad Basin (LCBC) is shown.

The author also shows that the war against Boko Haram seems to produce exceptional results that force both admiration and criticism of the Cameroonian people and the international community. The case of criticism by the NGO Amnesty International is analysed in details.
\end{abstract}

Key words: Cameroon, Africa, Regional Security, International Cooperation, Terrorism, Boko Haram

The emergence and then the growing development of terrorism in the northern region of Cameroon remains a relatively recent phenomenon. The first incursions of Boko Haram into Cameroon's territory date back to 2012 [Bokeriya, Omo-Ogbebor 2016] with great control of the terrain in this part of northern Cameroon, forcing the Cameroonian authorities to retaliate.

\section{ATROCITIES OF BOKO HARAM}

This threat of Boko Haram was accompanied initially by kidnappings, then demands for ransom and finally suicide bombings. The release of the first targeted persons, such as the Moulin-Fournier family, kidnapped on 19 February 2013 in the locality of Dabanga, eighty kilometers from Kousséri, or the French priest Georges Vandenbeusch, kidnapped at Nguetchéwe on 14 November 2013, are obvious illustrations. At the beginning of April 2014, Fathers Gianantonio Allegri, Giampaolo Marta and Sister Gilberte Bussière were captured with the traditional chief of the village of Goumouldi, who was found to have his throat cut in Nigeria; on the night of 16 to $17 \mathrm{May}$, ten Chinese nationals disappeared in Waza; the town of Kolofata is the subject of a spectacular assault during which the wife of the deputy prime minister Amadou Ali, his sister-in-law, the mayor and lamido of Kolofata are abducted. Seini Boukar Lamine, his wife, six of their children and several other members of the family. Since the end of July 2015, 
Cameroon has undergone some thirty suicide attacks in the Far North. If Boko Haram is suspected of infiltrating mosques and Koranic schools, the group recruits especially disadvantaged girls who have no idea that they carry bombs [Olivier 2015].

On February 9, 2015, about ten soldiers of the Rapid Intervention Battalion (BIR) were seriously injured, immediately from the jump of a vehicle on an "improvised explosive device" posed by the insurgents. Since the beginning of the war, 22 soldiers of Operation Alpha (BIR) - about 50 for all Cameroonian units - have lost their lives in ten months of almost daily confrontation with the sect [Dougueli 2015]. Even though this group of extremists is aiming to change specific policies or practices over the years, Cameroonian authorities should not underestimate their ability to endanger the life and social and economic welfare of the country.

According to the Cameroonian Government's various assessments, 1,098 civilians, 67 soldiers and 3 policemen were killed in exactions and other targeted attacks by Boko Haram terrorists in the Cameroonian extreme north since 2013. It should also be noted that this area bordering Nigeria has experienced 315 incursions from Boko Haram terrorists, 12 mine incidents and 32 suicide bombings since 2013. In 2014, up to 37 Boko Haram attacks against Cameroonian soldiers. This number was 23 Boko Haram attacks were perpetrated in 2015. As for the civilian populations, they underwent in 2014, about 66 attacks and various exactions by Boko Haram. This figure was 116 in 2015 and only five in the first 15 days of 2016. According to the assessment made by the Cameroonian Minister of Communication, spokesman of the Government, early in 2016, Cameroon underwent " 15 terrorist attacks perpetrated by Boko Haram. Among these attacks are two suicide attacks and a total of 10 people were killed, 11 wounded, nine abducted and six homes burned". Pillages, killings, kidnappings and suicide attacks have furnished this area during the year 2017 and the material and human damage are counted by ten. By way of illustration, an attack attributed to Boko Haram killed 15 people and kidnapped 8 people on 11 August $2017^{2}$.

\section{INTERNAL COUNTERTERRORISM RESPONSE}

Cameroonian state has put in place a defense and security arsenal to deal with the terrorist threat to its independence and sovereignty. These are the Ministry of Defense, the General Delegation for National Security (DGSN), the Directorate General for External Research (DGRE), the National Security Council (CNS), the CounterTerrorism Act voted by Parliament and the vigilance committees. For example, in February 2000, the authorities established "Operational Command" missions at the national level to deal with the rise of criminal acts. The creation of the "Operational Commands" makes it possible to entrust special police missions to the military, under the command of generals, on a provisional basis. However, a number of burrs have affected the deployment of these operational units, which, moreover, have not succeeded in solving political and development problems by systematically using expeditious methods. Prior to the establishment of the "Operational Commands", Cameroon had already created

${ }^{1}$ Cameroon Radio-Television (CRTV), 2016.

${ }^{2}$ Fifteen dead in an attack on Boko Haram in Cameroon. Journal L'oeil du Sahel. 17 August 2017. 
in 1999, the Light Battalion of intervention (BLI), transformed in 2008 into Rapid Intervention Battalion (BIR), an elite unit of the army, very engaged today in the fighting against Boko Haram.

Following the declaration of war at Boko Haram, in August 2014, the Cameroonian authorities also carried out a partial reorganization of the territorial map of the army's command by creating a specific military region, which groups together the departments most affected by the actions of the terrorist group. These decisions are part of what is similar to a readjustment of the concept of employment of forces in Cameroon. They reflect a new direction already begun in 2001, with the expansion of defense policy at the subregional level and the gradual redefinition of military the allocation of resources and tools adapted to these new missions [Ntuda Ebode, Koungou 2014].

National security itself has evolved with the creation of special police units (ESIR, GSO) over the last twenty years. Overall, of the 40,000 men represented by the FAC, 10,000 are special forces and units. The BIR and the GP alone bring together 6000 . The remaining 4000 are divided into BSA, FMC, FAI, etc. Cameroon thus has a soldier of third and fourth category. The forces of "3rd category" train little and are poorly equipped. On the other hand, those of "4th category" have training and equipment of high level, at least for the national and African context [Messe 2010].

In light of the modus operandi of Boko Haram, the Government of Cameroon has also taken certain measures concerning only the far north of the country, such as the creation of vigilance committees, the banning of regrouping and closure of drinking places after $6 \mathrm{pm}$, the increase in checks and searches, the strengthening of the forces in the North, with some 2,000 Cameroonian soldiers deployed in the Far North to officially increase the number of soldiers sent to the region to 8,500 , on the roads, the prohibition on the sale of cars, the restriction of the use of two-wheeled vehicles, the control of children used as kamikazes, the ban on wearing the full veil and the supervision of mosques.

Since 2014, Cameroon has declared an unlimited war against Boko Haram, which began with the bombing of their target and various riposte, while causing thousands of deaths and material damage on the enemy side. The Cameroonian response has, of course, made it possible to repel this invisible enemy and weaken it, but as long as the initial goal of reaching the leader and eradicate Boko Haram will be achieved? Doubt remains, and perhaps for a long time. For even if Boko Haram seems weakened, its exactions tend not to disappear, because suicide bombings are only perpetuated in the northern part of the country, as shown by the murderous attacks perpetrated by the Islamist sect since January 'in September 2017, with suicide bombings, for example, involving considerable material and human losses. That is to say, the important device deployed by the Cameroonian government since April 2014, namely: three thousand soldiers, bomber fighters, tanks and assault craft, runs up against a powerful organization that seems to be melting into the landscape [Nana Ngassam 2015].

\section{INTERNATIONAL COOPERATION: CASE OF MAJOR POWERS}

Cameroon's weakness in dealing with the terrorist threat has become increasingly evident through the vulnerability of its defense and security forces. This weakening of state structures and the threat of latent destabilization orchestrated by Boko Haram, 
particularly in the northern region, have become a matter of concern in international politics. The multiple, dramatic, murderous and asymmetrical attacks of Boko Haram in this part of the country led the Cameroonian president, Paul Biya, during his New Year's speech before the diplomatic corps (08 January 2015), to call a "global response" face this threat and international aid to address it [Cakpo Guedegbe 2015].

The major powers, but also the countries of the subregion and the African Union, have made Boko Haram on the defensive, although the participants at the 2016 summit in Abuja in Nigeria all acknowledge that the threat remains. This obviously leads to the scrutiny of the various international supporters of Cameroon in the fight against Boko Haram.

Cameroon is a traditional beneficiary of French military assistance. The last Defense Partnership Agreement between the two countries, signed in 2009, entered into force on 1 August 2012. This partnership consists mainly of training of personnel from various Cameroonian security forces and neighboring countries. They are provided by three establishments of the ENVR type (National School with Regional vocation): the International Superior School of War (ESIG) in Yaoundé ${ }^{3}$, the Center for the improvement of policing techniques the International School of Security Forces (EIFORCES) in Awaé ${ }^{4}$ and the national aeronautical center with regional vocation of Garoua ${ }^{5}$. In addition, the 2009 agreement provides for collaboration between the two countries in the area of intelligence sharing and the organization of joint military exercises. This agreement, unlike with other African countries, does not have a permanent French presence in Cameroon, nor military intervention inside the country, especially in the event of unrest [Leymarie 2009].

With the proliferation of incursions of Boko Haram in the Far-North region, and while Cameroon's public opinion was concerned about an attitude deemed passive and even complicit in France ${ }^{6}$, the formations were strengthened. Thus, in March and April 2015, in N'Gaoundéré and Garoua, French instructors gave training to combat shooting and demining to several dozen Cameroonian soldiers ${ }^{7}$. Six months later, also in N'Gaoundéré, France organized a series of training courses for Cameroonian special units involved in the fight against terrorism ${ }^{8}$, while in October, about forty Cameroonian officers went to Libreville for training courses in the fields of battalion command and combat warfare.

Furthermore, in March 2015, Paris announced the establishment, as at Diffa in Niger, of a liaison and contact detachment in Cameroon, charged with collecting intelligence

\footnotetext{
${ }^{3}$ International Graduate School of War (ESIG), Network of Francophone Expertise and Training for Peace Operations.

${ }^{4}$ raining in Homeland Security. France Diplomatie. June 2013.

5 France and Cameroon, Country files, France Diplomacy, undated; National Schools in Regional Involvement in Sub-Saharan Africa: France's support for multilateral efforts, Ministry of Foreign and European Affairs, October 2009.

${ }^{6}$ Cameroon: France responds to suspicions of complicity with Boko Haram and speaks of its involvement in the war against terrorists. Cameroon.Info.Net. February 23, 2015.

${ }^{7}$ Boko Haram: two French officers in Cameroon. Le Figaro. March 18, 2015.

${ }^{8}$ Military training: France alongside the Cameroon Defense Forces. Press release, French Embassy in Yaoundé, 6 October 2015.
} 
"on the ground" in the framework of Operation Barkhane. Composed of two officers, it was deployed in Maroua, chief town of the Cameroonian region most affected by Boko Haram ${ }^{9}$. In order to take stock of this collaboration, on 6 January 2016, President Biya received French officers, including General Pierre de Villiers, Chief of Staff of the Armed Forces, who called for a "pooling" of resources between among others, in the area of intelligence ${ }^{10}$. In terms of arms purchases, during the period 2010 - 2014, Cameroon imported a limited number of arms from France: the fifth supplier, surpassed by China, Spain, Russia and the United States. In terms of donations, France remains a major supplier to Yaoundé, again offering 11 fully equipped tactical vehicles in January 2016.

The Russian Federation is one of the first powers to join Cameroon in pushing back the incursions of armed Islamists. As of January 2015, the Head of the Russian Diplomatic Mission is received by the President of the Republic of Cameroon. HE Nicolay Ratsiborinski will assert to his host that his country will provide Cameroon with the military and technical assistance needed to overcome Boko Haram. Heavy artillery, missiles, air protection, anti-aircraft missile systems and guns will gradually equip the defense forces, and Russian military personnel sent for training in the use of this equipment.

At the level of American assistance in the fight against Boko Haram, the most significant event in 2015 was probably the arrival in Cameroon, on 12 October, of 90 US military personnel, vanguard of a total of 300 soldiers, in charge of "conducting airborne intelligence, surveillance and reconnaissance in the region", in the words of President Obama. Indeed, the United States had just created a new base of drones Predator in Garoua, capital of the Northern region ${ }^{11}$. The force was supposed to become fully operational when the total number of 300 troops expected to be reached by February $2016^{12}$. This US presence, albeit still modest, represents a sprain on Cameroonian traditional politics for more than half a century, for the permanent presence of foreign troops on its soil. Is it to better "pass the pill" that a few days later the commander of AFRICOM announced the donation to the Cameroonian army of six armored personnel carriers transporting mines? $?^{13}$ On the same day, the two countries signed a memorandum of understanding to strengthen their military cooperation ${ }^{14}$. Also, it should be emphasized that the threat of Boko Haram has therefore changed the situation in Cameroon. After the Chadian deployment in the Far North and the multiplication of French intelligence and training missions, the arrival of hundreds of US military personnel called into ques-

9 Boko Haram: France will deploy a liaison and contact detachment in Cameroon. Opex360.com. March 17, 2015.

${ }^{10}$ Two senior French military officials received by Paul Biya at the Palais de l'Unité. Yaoundeinfo.com. January 6, 2016.

${ }^{11}$ Obama sends U.S troops, drones to Cameroon in anti-Boko Haram fight. Reuters. October 14, 2015.

${ }^{12}$ Cameroon Welcomes US Assistance Against Boko Haram. Voice of America. January 1, 2016.

13 Fight against Boko Haram: Africom (U.S. Africa Command) offers armored vehicles to the Cameroonian Army. Cameroon-Info.Net. October 18, 2015.

${ }^{14}$ Cameroon: Six American Armored Vehicles Against Boko Haram. Cameroon Tribune. October 19, 2015. 
tion a certain conception of the sovereignty of the Cameroonian state. It remains to be hoped that what some will interpret as renunciations will produce results quickly, ie a significant reduction in the Boko Haram's nuisance capacity in the country.

The British government has invested heavily in the fight against Boko Haram. In April 2015, the Foreign Office announced the release of more than CFAF 4 billion to support the military effort of the Multinational Joint Force. This coalition of member countries of the Lake Chad Basin Commission plus Benin, set up to fight Boko Haram. What makes Brian Olley, United Kingdom High Commissioner for Cameroon, said: "The United Kingdom fully supports the efforts of Cameroon, Chad, Nigeria, Niger, Benin and other regional partners to fight the Boko Haram scourge. Important victories have already been recorded in the field. The mixed force will continue to play an important role in the fight against this terrorist insurgency" ${ }^{\prime 15}$. The United Kingdom therefore provides a non-exhaustive list of accompanying measures for Cameroon in the fight against Boko Haram.

Germany is also involved in the fight against terrorism in the world and mainly in Cameroon, both diplomatically and militarily. In November 2014 Germany handed over 120 vehicles to the Cameroonian army to fight Boko Haram. In detail, there are 60 Wolf jeeps, Mercedes and 60 Unimog-Mercedes trucks. Some of the trucks are fitted with quadrature $14.5 \mathrm{~mm}$ long-range artillery pieces. In addition, Germany offers a training period for Cameroonian military personnel to use this equipment. In February 2015, the German Chancellor pledged to financially support a fighting force against Boko Haram.

\section{MULTILATERAL EFFORTS}

The internationalization and regionalization of the counter-offensive against Boko Haram is assessed in the light of the concerted action of multiple actors, including foreign powers, member states of the Commission of the Lake Chad Basin (LCBC) and Benin, the Joint Multinational Force (FMM), the Multinational Joint Task Force (MNJTF) $)^{16}$. Following the summit in Addis Ababa on 30 and 31 January 2015, the African Union adopted the principle of deploying a 7,500-strong African force to fight Boko Haram. The African Union also called on the UN Security Council to seek international funding, as promised by the European Union, to support the fight against the Islamist sect.

It should be noted that the international community is not inactive and numerous summit meetings have taken place, notably in Paris on 17 May 2014. The major resolution of the summit was the elaboration of a co-ordination between several countries weakened by the boko-haram exactions, specifically the strengthening of increased cooperation between Nigeria and Cameroon, which was consolidated by the visit of President Muhammadu Buhari in Yaoundé, from 28 to 30 July 2015, with a view to discussing security issues between the two countries. In line with the Paris Summit, Nigeria hosted

15 The United Kingdom is offering 4.4 billion CFA francs for the Multinational Joint Force. Journalducameroun.com, 06/04/2015.

${ }_{16}$ The European Union (EU) pledges to provide $\$ 55$ million in funding to the regional force to fight Boko Haram. Nigeria, BBC Africa. 02 August 2016. 
an international summit on the fight against Boko Haram on 14 May 2016 in order to assess regional action against Boko Haram and adopt a collective strategy capable of managing the consequences of this crisis on security, development, governance, socioeconomic and humanitarian situation.

The United Nations Security Council, at its 7492nd meeting, on 28 July 2015, called on the international community and donors to finance the Multinational Joint Task Force on Security to strengthen regional military cooperation and effectively against the threat represented by the terrorist group Boko Haram for the Lake Chad Basin region and for international peace and security. It should be noted that the instruments implemented in the framework of this international public action are bilateral before being regional and international, as illustrated by the two summit meetings between President Biya and his Nigerian counterpart Muhamadou Buhari. Indeed, these meetings which took place in July 2015 in Yaoundé and in May 2016 in Abuja, had as a highlight the fight against Boko Haram in all its declensions. With regard to the legal instruments, the Cameroonian parliament adopted at its session of November 2014 the law repressing acts of terrorism in Cameroon. This Act is part of the internal implementation of international measures to combat terrorism. On relevance, this law is adopted in a context where acts of Boko Haram have caused many tragedies and that the release of these hostages in Cameroon was effective, with a few exceptions.

\section{REACTION OF NEIGHBOURS}

The transnationalization of the Boko Haram nebula following its "de-fertilization" plunged the region of Lake Chad into the vicious circle of terror. Faced with a movement that has taken advantage of the icy and suspicious relations between states to move in total contempt of national borders, the strengthening of collective security mechanisms has quickly become an imperative.

Chad has always shown hegemonic inclinations in an area that it considers to be acephalous. By projecting its forces into several theaters of operations and responding promptly to the demands of its peers in the subregion, Chad wants to carve out a reputation as a stabilizing leader ${ }^{17}$. Chad's intervention is justified on the one hand by its fear that the city of Maroua, which has become the regular target of Boko Haram attacks in the summer of 2014, does not fall into the Islamist orbit. which would have meant the closure of the N'Djamena-Kousserie transnational road, Kousserie-Maroua, which nevertheless represents the channel of rallying of Chad [Nkalwo Ngoula 2015] to the coast of Cameroon, that is to say to the port of Douala, main maritime outlet of Chad. It is therefore in order to secure the supply lines vital to its economy that Chad has decided to invest in the fight against Boko Haram. Moreover, for geopolitical motives, by positioning itself as the spearhead of the fight against terrorism in Africa, Chad is now a must in the eyes of the French and Americans who are increasingly worried about the rise of jihadist currents in sub-Saharan Africa [Chad 2016].

As the fifth largest foreign direct investment destination in the continent, Nigeria has seen a gradual withdrawal of investors since its security situation deteriorated.

${ }^{17}$ Central Africa: Risks and Reversal of the Pax Tchadiana. GRIP. February 2014. 
The murderous violence of the Islamist movement and the indiscriminate repression of the Nigerian army have resulted in an influx of Nigerian refugees into Cameroonian territory [Bakare 2016]. It seems that the elements of Boko Haram infiltrated in these populations to find refuge in Cameroon. The humanitarian crisis that followed this movement has taken the Cameroonian authorities already hampered by the massive presence of Central African refugees in their territory at the same time. It is with a view to curbing this financially unsustainable and socially struggling flow of refugees in view of the intercommunity tensions which, it could sustain due to the pressure on resources - that Cameroon and Nigeria are invested in the fight against the terrorist group.

However, the question of the regional institution that could house the FMM arose at the beginning of the cooperation. The affiliation of the Nigeria-Niger couple to ECOWAS and the Cameroon-Chad couple to ECCAS required a joint platform of cooperation to be revived in the four states, the Lake Chad Basin Commission (LCBC) shown in the past its inability to prevent conflicts arising from Nigeria's claims on parts of Lake Chad.

The contribution of South Africa, which equipped the BIR with at least a dozen armored vehicles in December $2015^{18}$, can not be put under the wheel.

\section{PERCEPTION OF COUNTER-TERRORIST ACTIVITIES}

Perception expresses the representation made by any decision-maker of the national, regional or global environment [Heam 1986]. Thus, the war against Boko Haram seems to produce exceptional results that force the admiration and criticism of the Cameroonian people and the international community. To account for this dichotomous conception of the struggle against this nebula, it is necessary to distinguish the image that each of them has of this war. According to Boulding, "the image is the organized representation of an object in the cognitive system of the individual" [Heam M 1986]. It is therefore a matter of questioning the place that this war occupies in the imaginary of the various sociological components.

The merciless struggle of the terrorist threat in Cameroon not only posed security and economic challenges for the partner states but also opened a window of criticism from non-governmental organizations (NGOs), such as Amnesty International. The NGO Amnesty International has repeatedly criticized the detention outside the national and international legal framework of individuals captured by the Cameroonian armed forces. Detention without limit and under degrading conditions, the procedures in which certain prisoners are tried, and the acts of torture practiced on prisoners are all points denounced by this NGO. On the basis of dozens of testimonies corroborated by satellite imagery, photos and videos, the report entitled Chambers of torture secret in Cameroon: human rights violations and war crimes in the fight against Boko Haram gathers information on 101 cases of incommunicado detention and torture that took place between 2013 and 2017 on more than 20 different sites ${ }^{19}$. "We have always unequivocally condemned

${ }^{18}$ Fight against Boko Haram: South African tanks for the Cameroonian army. Camerpost. January 19, 2016.

19 www.amnesty.org/.../cameroon-amnesty-report-reveals-war-crimes-in-fight-ag, on 20/07/2017. 
the atrocities and war crimes committed by Boko Haram in Cameroon. Nevertheless, nothing can justify the ruthless and widespread use of torture by the security forces against ordinary Cameroonians, who are often arrested without proof and are subjected to unimaginable suffering", said Alioune Tine, West and Central Africa to Amnesty International.

The Cameroonian people do not deprive themselves of playing the card of defense of the interests of Cameroon in this war and to oppose the condemnations of Amnesty International. Jacques Yoki Onana, Mayor of the Commune of Yaounde VI takes exception to the report of the NGO: "A true heresy" "I read with some interest the last report of the NGO Amnesty International on the alleged abuses against the members of the Islamist sect Boko Haram by our defense and security forces. This immediately leads to the question: who is now the victim in this conflict? I would like these Amnesty International people who write their reports to take the place of those men and women whom Cameroon has been mobilizing for years to protect, leaving their families for months on end, some of whom leave their lives behind. Let them take the place of Cameroon which mobilizes enormous resources, which could have been used for its development, to face this aggression. In the end, this report is a heresy. We continue to reaffirm our support for the Head of State and our valiant soldiers in this war"20.

Moreover, the war against Boko Haram has involved a long series of external interventions since 2014, which led the allies of Cameroon to show solidarity against this aggression. What is to be retained is the variety of configurations of external interventions, depending on the country. Of course, the role of senior leaders must be taken into account when making decisions about interventions. The responsible powers, endowed with great diplomacy, are committed to accompany Cameroon in this war. But this external contribution does not seem to be the object of criticism. According to Vincent Ntuda Ebode, "Africans must not lose sight of the fact that counter-terrorism and the fight against piracy can hide other motivations. They can divert the attentions of the countries concerned on the essential: the plundering of the natural resources of the country, among others the oil drawn off its waters or the export of citrus fruits. The popular chronicle gave French diplomacy a cold sweat. In the cottages and in the bistros, one sees the hand of Paris behind Boko Haram "to destabilize the Cameroon" [Ntuda Ebode 2010]. Not destabilized by this witch-hunt, the former colonial power will reaffirm its position against terrorism and provide its political, diplomatic, and military support in Cameroon.

Cameroon and its partners commit themselves to further strengthening security in the northern part of the country. In the medium term, reflections could focus not only on improving the effectiveness of permanent structured cooperation to fight the Islamist sect, but also on managing refugees. Given that the challenge of terrorism and the refugee problem have their roots in the immediate vicinity of Cameroon, it would be necessary to have a good Central African Neighborhood Policy in order to counteract the terrorist attacks carried out to this day in this part of the country.

${ }^{20}$ Cameroon - Boko Haram: This is what politicians think of Amnesty's damning report. International. 24 July 2017. 


\section{REFERENCES}

Bakare, I.A. (2016). Soft Power as a means of fighting international terrorism: a case study of Nigeria's "Boko Haram". Vestnik RUDN. International Relations, 16 (2), 285-295.

Bokeriya, S.A. \& Omo-Ogbebor, D.O. (2016). Boko Haram: A new paradigm to West Africa Security Challenges. Vestnik RUDN. International Relations, 16 (2), 274-284.

Cakpo Guedegbe, B. (2015). Boko Haram: Armed arm of international terrorism, Destabilization of Nigeria and reconfiguration. Geopolitics of the Sahelian zone, IRIS, Observatoire géopolitique du Religieux (in French).

Chad: between ambitions and fragilities (2016). International Crisis Group, Africa Report $\mathrm{N}^{\circ} 233$.

Dougueli, G. (2015). Cameroon: the army facing the octopus Boko Haram. Jeune Afrique. 20 Mai (in French).

Gautier, L. (2016). The ways and means of combating terrorism. Pouvoirs. French review of constitutional and political studies. 158, 39-50 (in French).

Heam, M. (1986). The perception. French Revue de science politique. 36 (in French).

Koungou, L. (2015). Strategic culture and defense concept in Cameroon. Paris: Harmattan.

Laurens, H. (2010). Terrorism as a Historical Person, in Laurens H. \& Delmas-Marty, M. (ed.). Terrorisms. History and law. Paris, CNRS éditions. P. 9-66 (in French).

Leymarie, P. (2009). France-Africa: new-generation military agreements. Le Monde diplomatique. June (in French).

Messe, L. (2010). The Staff of the Armed Forces and the Training of Forces. Memory of the Master of Security, Defense, Strategy and Conflict Management. University of Yaoundé, CREPS.

Nana Ngassam, R. (2015). Cameroon under the threat of Boko Haram. Le Monde Diplomatique. January.

Nkalwo Ngoula, J-L. (2016). Understanding the determination of Chad in the fight against Boko Haram. International Crisis Group, Africa Report N ${ }^{\circ} 233$, March.

Ntuda Ebode, J-V \& Kongou, L. (2014). Boko Haram: imbroglio in northern Cameroon. Revue Défense nationale. No. 775, December (in French).

Olivier, M. (2015). Terrorism: who are the suicide bombers of Boko Haram in Cameroon? Jeune Afrique. 12 Aôut (in French).

Received 23.08.2017

For citations: Kouma, J.C.G. (2017). Cameroon Fighting Boko Haram. Vestnik RUDN. International Relations, 17 (4), 727-737. DOI: 10.22363/2313-0660-2017-17-4-727-737.

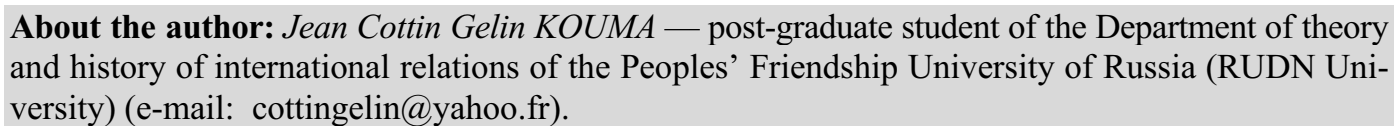

DOI: $10.22363 / 2313-0660-2017-17-4-727-737$

\section{КАМЕРУН В БОРЬБЕ С «БОКО ХАРАМ»}

\section{Ж.К.Ж. Кума}

Российский университет дружбы народов, Москва, Россия

В данном исследовании описаны преступления террористической группы «Боко Харам» в Камеруне, а также история международного сотрудничества в борьбе против данной исламистской секты с момента объявления войны против нее в 2014 г. Показаны основные антитеррористические 
усилия Камеруна, в том числе создание «Оперативных командований», частичная реорганизация территориальной обороны, расширение оборонной политики на субрегиональный уровень и постепенная передислокация военных, распределение ресурсов и резервов с учетом новых задач.

Камерун участвует в процессе многостороннего контртеррористического сотрудничества, которое придает новый импульс действиям национальных сил обороны и безопасности. Выявлена роль основных держав и стран субрегиона, а также Африканского союза и Организации Объединенных Наций в борьбе с «Боко Харам». Камерун является традиционным бенефициаром французской военной помощи. Антитеррористическая помощь также поступает из России, США, Великобритании и Германии. Показана роль Многонациональной объединенной целевой группы Комиссии бассейна озера Чад.

Автор также показывает, что война против «Боко Харам» вызывает одновременно одобрение и критику как со стороны камерунского народа, так и международного сообщества. Подробно разбирается анализ критики со стороны НПО «Международная амнистия».

Ключевые слова: Камерун, Африка, региональная безопасность, международное сотрудничество, терроризм, «Боко Харам»

Дата поступления статьи: 23.08.2017

Для цитирования: Кума Ж.К.Ж. Камерун в борьбе с «Боко Харам» // Вестник Российского университета дружбы народов. Серия: Международные отношения. 2017. Т. 17. № 4. С. 727737. DOI: $10.22363 / 2313-0660-2017-17-4-727-737$.

Сведения об авторах: Жан Котэн Желэн Кума - аспирант кафедры теории и истории международных отношений Российского университета дружбы народов (e-mail: cottingelin@yahoo.fr).

(C) Kouma J.C.G., 2017 